\title{
MICROSCOPIA ELETRÔNICA DE VARREDURA E ESPECTROSCOPIA DE ENERGIA DISPERSIVA DE EMBALAGENS AUTOCLAVÁVEIS SUBMETIDAS A SUCESSIVOS CICLOS DE ESTERILIZAÇÃO EM ÁGUA DESTILADA OU FLUORETADA
}

\author{
SCANNING ELECTRON MICROSCOPY AND DISPERSIVE ENERGY \\ SPECTROSCOPY OF AUTOCLAVABLE PACKAGING SUBMITTED TO \\ SUCCESSIVE CYCLES OF STERILIZATION WITH DISTILLED OR \\ FLUORIDATED WATER
}

\author{
Larissa Sanches PUPO', Mario Augusto RIBAS Junior ${ }^{1}$, Angélica Resnizek DINIZ', \\ Juliana Silva do NASCIMENTO ${ }^{2}$, Vitoldo Antonio KOZLOWSKI Junior ${ }^{3^{*}}$ \\ ${ }^{1}$ Acadêmicos do Curso de Odontologia da Universidade Estadual de Ponta Grossa. \\ ${ }^{2}$ Professora do Departamento de Odontologia da Universidade Estadual de Ponta Grossa. \\ $3^{*}$ Autor para contato: Prof. Dr. Associado de Periodontia do Curso de Odontologia da \\ UEPG. Universidade Estadual de Ponta Grossa, Setor de Ciências Biológicas e da Saúde, \\ Laboratório de Pesquisa do Grupo Acubens - Rua: Carlos Cavalcanti 4748 - Uvaranas, \\ Ponta Grossa PR - Brasil - CEP 84030-900. E-mail: vakozlowski@uepg.br, (42)3220 3104.
}

\begin{abstract}
RESUMO
Os processos de esterilização sofrem constantes aperfeiçoamentos, a fim de oferecer materiais odonto-médico-hospitalares isentos de micro-organismos patogênicos. Este estudo teve como objetivo realizar uma avaliação sobre o efeito de ciclos sucessivos de utilização de embalagens de papel grau cirúrgico e filme laminado VedaMax ${ }^{\circledR}$ no processo de esterilização de artigos odontológicos em autoclave a vapor saturado sob pressão com água destilada ou água fluoretada. A avaliação experimental foi realizada utilizando 56 amostras (papel=28 e plástico $=28$ ); 8 não esterilizados, 16 com 1 ciclo de esterilização, 16 com 2 ciclos de esterilização e 16 com 3 ciclos de esterilização. Metade das amostras submetidas a ciclos de esterilização foi esterilizada com água destilada e a outra metade com água fluoretada de sistema de abastecimento de água. Essas amostras foram analisadas por MEV e EDS. Foi realizada a contagem de microporos e análise das larguras das fibras. Indicadores químicos e biológicos foram utilizados nos pacotes para testar a eficácia da esterilização. Houve deformação física das embalagens com diminuição do número de poros $(\mathrm{p}<0,001)$ e aumento na largura das fibras $(\mathrm{p}<0,05)$. Os testes biológicos indicaram esterilização, mas as amostras foram rejeitadas em testes ao utilizar indicador do tipo integrador químico. Houve contaminação por matéria inorgânica com uso de água fluoretada e destilada, com a reutilização das embalagens. Concluiu-se que reutilizar embalagens aumenta o risco de oxidação e degradação dos instrumentais, além de colocar em risco o processo de esterilização.
\end{abstract}

Palavras-chave: Papel grau cirúrgico. Filme laminado. Esterilização. Autoclave a vapor saturado. Embalagens autoclaváveis. Flúor.

\begin{abstract}
The sterilization processes suffer constant improvements in order to offer dentistrymedical-hospital materials pathogenic-free. The aim of this study was to evaluate the effect of the autoclavable packaging VedaMax ${ }^{\circledR}$ submitted to successive cycles of sterilization in the saturated steam autoclave under pressure with distilled or fluoridated water. This experimental evaluation was conducted in 56 samples (paper $=28$ and plastic $=28$ ); 8
\end{abstract}


without sterilization, 16 with one sterilization cycle, 16 with two sterilization cycles and 16 with three sterilization cycles. Half of the samples were sterilized with distilled water and the other half with fluoridated water from the water-supply system. These samples were analyzed through MEV and EDS. The micropore count and analysis of the widths of the fibers were performed. Chemical and biological indicators were used in the packages, being reused to test the effectiveness of sterilization. A physical deformity of the packaging occurred with a decrease in the number of pores $(p<0,001)$ and in the width of the fibers $(p<0,05)$. The biological tests indicated sterilization, but the samples were rejected in tests using integrator chemical. There was contamination by inorganic matter through the use of fluoridated and distilled water, with the reuse of the packaging. We concluded that reusing packaging increases the risk of oxidation and degradation of instrumental, besides putting the sterilization process at risk.

Keywords: Surgical grade paper. Laminated film. Sterilization. Steam saturated autoclave. Autoclavable packaging. Fluoride.

\section{INTRODUÇÃO}

A Central de Material e Esterilização (CME) é considerada, pelo Ministério da Saúde (MS), uma unidade de apoio técnico, cuja finalidade é fornecer produtos e materiais adequadamente processados, proporcionando condições para o atendimento direto e a assistência à saúde de indivíduos enfermos e/ou sadios (ANVISA, 2002; ASCARI et al., 2013). O reprocessamento de produtos e materiais na clínica médico-odontológica, visando à diminuição de custos operacionais, tem gerado controvérsias em torno da efetividade e da qualidade da esterilização, necessitando ser constantemente re-avaliado por causa de novos produtos e materiais que são comercializados (COSTA et al., 2011). A resolução ANVISA RE 2605 (2006) estabeleceu uma lista de 66 produtos médico-odontológicos de uso único proibidos de serem reutilizados, estando em $28^{\circ}$ lugar as embalagens descartáveis para esterilização de qualquer natureza (COUTO et al., 2009). Além disso, essas embalagens devem atender a requisitos mínimos estabelecidos por normas nacionais (ABNT, 2005a; ABNT, 2005b), para que sejam compatíveis com os processos de esterilização. O empacotamento dos materiais é de grande importância na qualidade da esterilização. Para isso, as embalagens devem possuir características físicas; possuírem custo/benefício positivo; terem resistência e compatibilidade com as condições físicas do processo de esterilização, fornecendo uma adequada proteção do conteúdo interno contra danos físicos. As embalagens também não podem apresentar substâncias tóxicas antes ou depois do processo de esterilização; devem evitar a liberação de partículas e fibras; serem hidrorepelentes; resistentes a punções e rasgos, permitindo uma selagem para um fechamento adequado. Adicionalmente, devem possibilitar a entrada do agente esterilizante; permitir a remoção do ar de dentro da embalagem adequadamente; proporcionar barreira antimicrobiana, antifúngica e antiviral; ter baixa memória e possibilitar uma abertura asséptica (SOBECC, 2009).

Compete ao Cirurgião-Dentista assegurar os processos de limpeza, de desinfecção e de esterilização dos artigos e dos instrumentais odontológicos. Além disso, o profissional da saúde deve estar atento para a escolha da embalagem e dos critérios corretos para a sua utilização, uma vez que essas condições estão inclusas na efetividade do sucesso da esterilização. Essas embalagens são constituídas de papel grau cirúrgico e filmes laminados (plástico), materiais que permitem a passagem do vapor e que podem ser encontrados em envelopes prontos e rolos. De acordo com os fabricantes, esses materiais são descartáveis, mas, no dia a dia, existem relatos de reutilização dessas embalagens e substituição da água destilada por água fluoretada do sistema de abastecimento público. Isso estaria acontecendo para minimizar o custo do processo de esterilização (DINIZ et al., 2013), deixando a dúvida se o material envolvido estaria sendo submetido a uma esterilização eficiente. Dessa maneira, esta pesquisa experimental foi conduzida para identificar quais as consequências e os efeitos da utilização de sucessivos ciclos de esterilização em água destilada ou água fluoretada, sobre embalagens autoclaváveis e se os materiais utilizados nestas embalagens (papel e 
plástico) poderiam proporcionar efetivos e confiáveis processos de esterilização.

\section{MATERIAIS E MÉTODOS}

\section{Amostras e grupos experimentais}

Foram utilizadas amostras de embalagens para esterilização constituídas de papel grau cirúrgico e filme laminado (plástico) fornecido em rolos da marca VedaMax $^{\circledR}$ (Brasil). Para as análises foram utilizadas 56 amostras, distribuídas em dois grupos: papel e plástico. Cada grupo foi subdividido em sete subgrupos: a) Subgrupo 1: sem esterilizar; b) Subgrupo 2: um ciclo de esterilização com água destilada; c) Subgrupo 3: dois ciclos de esterilização com água destilada; d) Subgrupo 4: três ciclos de esterilização com água destilada; e) Subgrupo 5: um ciclo de esterilização com água fluoretada (água encanada e filtrada); f) Subgrupo 6: dois ciclos de esterilização com água fluoretada; g) Subgrupo 7: três ciclos de esterilização com água fluoretada. Para a realização das avaliações foram preparadas quatro amostras em cada subgrupo.

\section{Procedimento de esterilização}

Os recipientes foram devidamente embalados em papel grau cirúrgico com as cubas viradas com sua abertura para o papel da embalagem e para o filme laminado (plástico). Todas as embalagens foram fechadas com fita crepe com marcador de temperatura da marca $3 \mathrm{M}^{\circledR}$ (Brasil). Em cubas de inox de uso odontológico, foram colocadas oito amostras, quatro de papel grau cirúrgico e quatro de filme laminado. Uma cuba com as amostras foi submetida a apenas um ciclo de esterilização com uso de água destilada e outra esterilizada uma vez em autoclave com uso de água fluoretada do sistema de abastecimento público. Outros dois recipientes com as amostras foram submetidos a dois ciclos de esterilização, sendo um utilizando água destilada e o outro, água fluoretada. Estes, após o primeiro ciclo, receberam novas embalagens externas ao recipiente. Da mesma forma, outros dois recipientes com as amostras foram submetidos a três ciclos de esterilização, um com uso de água destilada e outro com água fluoretada, com as embalagens externas sendo trocadas após o primeiro e o segundo ciclo. Oito amostras, quatro de cada grupo, não foram esterilizadas, mas também foram analisadas e serviram como controle. Para a realização dos ciclos de esterilização com água destilada, foi utilizada autoclave da marca Cristófoli ${ }^{\circledR}$, modelo - LI-XXI (BRASIL, 1996), e, para os ciclos de esterilização com água fluoretada, uma autoclave da marca SERCON ${ }^{\circledR}$ modelo - HAE19 (BRASIL, 1996).

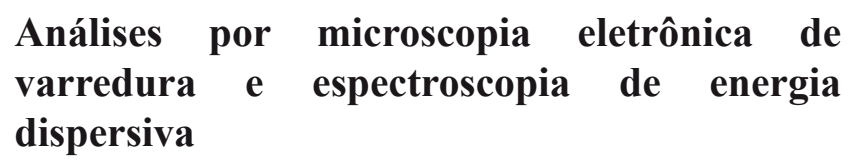

Todas as amostras foram submetidas a uma impregnação a ouro com o uso de um metalizador da marca Shimadzu ${ }^{\circledR}$ modelo - IC-50 (Japão). Essa impregnação consistiu de uma cobertura ultrafina desse material eletricamente condutivo que foi depositado para melhorar o contraste das imagens e prevenir a acumulação de campos elétricos estáticos nas amostras, devido à irradiação elétrica durante a produção da imagem no microscópio eletrônico de varredura (MEV). O MEV utilizado foi da marca Shimadzu ${ }^{\circledR}$ modelo SS-550 (Japão), equipado com um analisador de espectroscopia de energia dispersiva (EDS), marca Shimadzu ${ }^{\circledR}$ modelo SEDX-550 (Japão). Imagens obtidas pelo microscópio eletrônico de varredura forneceram informações como o número de microporos em uma aparência tridimensional característica, largura e disposição das fibras no papel grau cirúrgico e aparência do filme laminado, contaminação e possíveis deformações em sua superfície. Ao fazer análises com EDS em cada subgrupo, foi possível obter quais elementos químicos estavam presentes e a percentagem em massa atômica desses elementos nas amostras.

\section{Análise de microporos}

Em uma área de 191.288,74 $\mu \mathrm{m}^{2}$ (ou 0,191 $\mathrm{mm}^{2}$ ) do papel grau cirúrgico, foi feita uma contagem do número de microporos em todas as amostras. As imagens foram visualizadas pelo programa Microsoft Office Document Imaging ${ }^{\circledR}$ (Beijing, China). Os microporos foram contados individualmente e, durante a contagem visual, receberam marcações para não serem incluídos novamente na avaliação.

\section{Análise das larguras das fibras do papel grau cirúrgico}

Medidas das larguras das fibras em todas as amostras foram realizadas em uma área de 191.288,74 $\mu \mathrm{m}^{2}$, observando-se alterações morfométricas das fibras ao serem submetidas a ciclos de esterilização por 
calor úmido, utilizando-se o programa UTHSCSA Image Tool ${ }^{\circledR}$ (San Antonio, Texas).

\section{Verificação da eficácia de esterilização nas autoclaves a vapor utilizadas}

Monitoramento dos processos de esterilização foi realizado utilizando testes químicos e microbiológicos. Para os testes químicos, foram utilizados dois indicadores externos: a fita crepe para uso em autoclave a vapor, que possui listras em diagonal e um corante impresso em sua superfície, que muda de cor quando exposto ao agente esterilizante; e o indicador da embalagem. Para os testes químicos internos, foi utilizado o indicador integrador químico interno classe 5 , que consiste em uma tira de papel com um agente químico que sofre mudança progressiva e visível ao longo de um mostrador e monitora todos os parâmetros do processo de esterilização, como temperatura, vapor e tempo. Os testes microbiológicos (interno) utilizados foram de um indicador de segunda geração, que foi utilizado para comprovar morte microbiana após a esterilização.

Cada indicador interno (um químico e um microbiológico) foi colocado dentro de uma cuba junto ao material de uso odontológico. Para realização dos testes, foram distribuídos em dois grupos. O primeiro com a abertura da cuba virada para o papel; o segundo com a cuba virada para o plástico conforme descrição no item Amostras e grupos experimentais. Os indicadores foram colocados em embalagens utilizadas pela primeira vez no processo de esterilização com uso de água destilada e fluoretada; colocados em embalagens reutilizadas pela segunda vez; e indicadores colocados em embalagens reutilizadas pela terceira vez em processo de esterilização com uso de água destilada e fluoretada. Para evitar que a embalagem rasgasse ao abrir, para depois poder reutilizá-la, foi cortada com uma tesoura uma das extremidades das embalagens onde a fita com indicador químico selava. $\mathrm{O}$ indicador interno foi, então, removido, identificado e armazenado, e um novo colocado no recipiente e fechada a embalagem com fita.

\section{Indicador químico externo de esterilização em autoclave a vapor impresso na embalagem VedaMax $^{\circledR}$}

Esses indicadores químicos estão fixados em trechos da embalagem de papel grau cirúrgico, impregnados com uma tinta termocrômica que muda de cor quando expostas à temperatura elevada por certo tempo. Isso indica apenas se o material passou ou não pelo processo de esterilização, e só é válido se a embalagem estiver sendo utilizada uma única vez.

\section{Indicador químico externo na fita crepe para autoclave}

Foi utilizada fita adesiva da marca 3M, também conhecida como fita-teste ou fita zebrada, que é designada para identificação de materiais esterilizados. Essa fita foi fixada nas embalagens previamente ao ciclo de esterilização, possui listras e um corante impresso em sua superfície e muda de cor ao passar pelo processo de esterilização.

\section{Integrador químico}

Análise química da eficácia de esterilização foi realizada com o Comply SteriGage ${ }^{\circledR}$ da marca $3 \mathrm{M}$ classe 5, que permite monitorar as condições da esterilização em autoclave a vapor no interior das embalagens e capaz de reagir a todos os parâmetros críticos da esterilização a vapor saturado sob pressão. No total, foram utilizados 12 indicadores de integrador químico, $6 \mathrm{em}$ cubas viradas para o plástico, e 6 com a cuba virada para o papel, sendo dois indicadores por subgrupo.

\section{Indicador biológico}

Os indicadores biológicos são projetados para possuírem suspensões de esporos bacterianos para controle dos processos de esterilização a vapor saturado. Foi utilizado um indicador do tipo auto-contido de segunda geração, o Attest $1262^{\circledR}$ B.I./Steam da marca $3 \mathrm{M}$, composto por uma tira de papel com uma população microbiana mínima de 100.000 esporos secos e calibrados de Geobacillus stearothermophilus. A tira foi armazenada em uma ampola plástica que também acondicionou uma ampola de vidro contendo um caldo nutriente próprio para o cultivo de micro-organismos. A ampola plástica foi fechada por uma tampa marrom perfurada e protegida por um papel de filtro hidrofóbico. Após cada indicador ter passado pela esterilização, ele recebeu uma identificação e sua ampola de vidro interna quebrada, de forma que os esporos bacterianos tivessem acesso ao caldo nutritivo, e então colocado em uma incubadora Attest $118^{\circledR}$ da marca $3 \mathrm{M}$ específica para esta geração do indicador biológico, a $57^{\circ} \mathrm{C}$, por 48 horas. Na incubadora, também foi colocada uma 
ampola de indicador biológico sem ter sido esterilizada. O método de leitura é por alteração da coloração do meio de cultura. Quando há crescimento microbiano, torna-se amarelo, e, quando não há crescimento, permanece na cor roxa. Foram utilizados 13 indicadores biológicos, sendo um não submetido à esterilização, seis armazenados em recipientes com a abertura para o papel, e seis com a abertura da cuba virada para o plástico, sendo dois de cada subgrupo.

\section{Análise estatística}

Todas as amostras foram submetidas a análise estatística para verificar a normalidade dos dados por meio do teste de Kolmogorov-Smirnov, seguido de Análise de Variância (ANOVA) e teste de Tukey para comparação entre os grupos do número de poros e teste de Kruskal-Wallis e teste de comparação múltipla de Dunn para a largura das fibras.

\section{RESULTADOS}

Os dados coletados na análise por espectroscopia de energia dispersiva (EDS) forneceram o percentual em massa atômica dos elementos presentes no papel grau cirúrgico (Tabela 1) e no filme laminado (Tabela 2). O elemento ouro apareceu nos resultados pelo fato da impregnação metálica ter sido realizada para o preparo das amostras. Esses resultados mostraram a maior presença de elementos químicos em todos os ciclos utilizando água fluoretada (Figura 1) e quando as embalagens esterilizadas com água destilada sofreram mais de um ciclo de esterilização (Figura 2).

Tabela 1 - Percentagem em massa atômica (\%) dos elementos presentes no papel grau cirúrgico por análise EDS

\begin{tabular}{|c|c|c|c|c|c|c|c|}
\hline Elementos & Sem esterilizar & A.D. ${ }^{A}$ & A.D. $2^{B}$ & A.D. $3^{\mathrm{C}}$ & A.F.1 ${ }^{\mathrm{D}}$ & A.F. $2^{\mathrm{E}}$ & A.F.3 ${ }^{F}$ \\
\hline $\mathbf{N}$ & 18.28 & & 36.99 & & & & \\
\hline $\mathbf{O}$ & 49.43 & 63.20 & 16.99 & 37.92 & 18.51 & 33.67 & 61.37 \\
\hline $\mathbf{A u}$ & 32.27 & & 9.00 & 18.92 & 40.67 & & \\
\hline $\mathrm{Na}$ & & & 18.07 & 9.42 & & & \\
\hline Mg & & & 0.63 & & & & \\
\hline Cl & & & 18.30 & 8.58 & & & \\
\hline Si & & & & 1.06 & 4.28 & 1.61 & \\
\hline $\mathbf{K}$ & & & & 5.28 & & & \\
\hline $\mathrm{Fe}$ & & & & 18.79 & & & \\
\hline $\mathbf{F}$ & & & & & 1.19 & & 2.57 \\
\hline $\mathrm{Ca}$ & & & & & & 3.46 & \\
\hline $\mathrm{Zn}$ & & & & & & 18.46 & \\
\hline C & & 36.79 & & & 35.33 & 42.78 & 36.05 \\
\hline Total & 99.98 & 99.99 & 99.98 & 99.97 & 99.98 & 99.98 & 99.99 \\
\hline
\end{tabular}

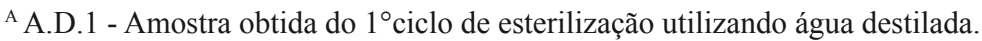

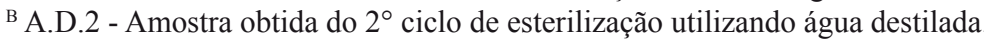

${ }^{\mathrm{C}}$ A.D. 3 - Amostra obtida do $3^{\circ}$ ciclo de esterilização utilizando água destilada.

${ }^{D}$ A.F.1 - Amostra obtida do $1^{\circ}$ ciclo de esterilização utilizando água fluoretada.

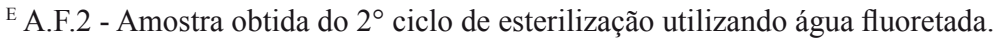

${ }^{\text {F }}$ A.F.3 - Amostra obtida do $3^{\circ}$ ciclo de esterilização utilizando água fluoretada. 
Figura 1 - Espectroscopia de energia dispersiva (EDS) realizada de amostra de papel grau cirúrgico submetida a um ciclo de esterilização com água fluoretada, demonstrando a presença dos elementos químicos $\mathrm{C}, \mathrm{O}, \mathrm{F}, \mathrm{Si}$ e Au

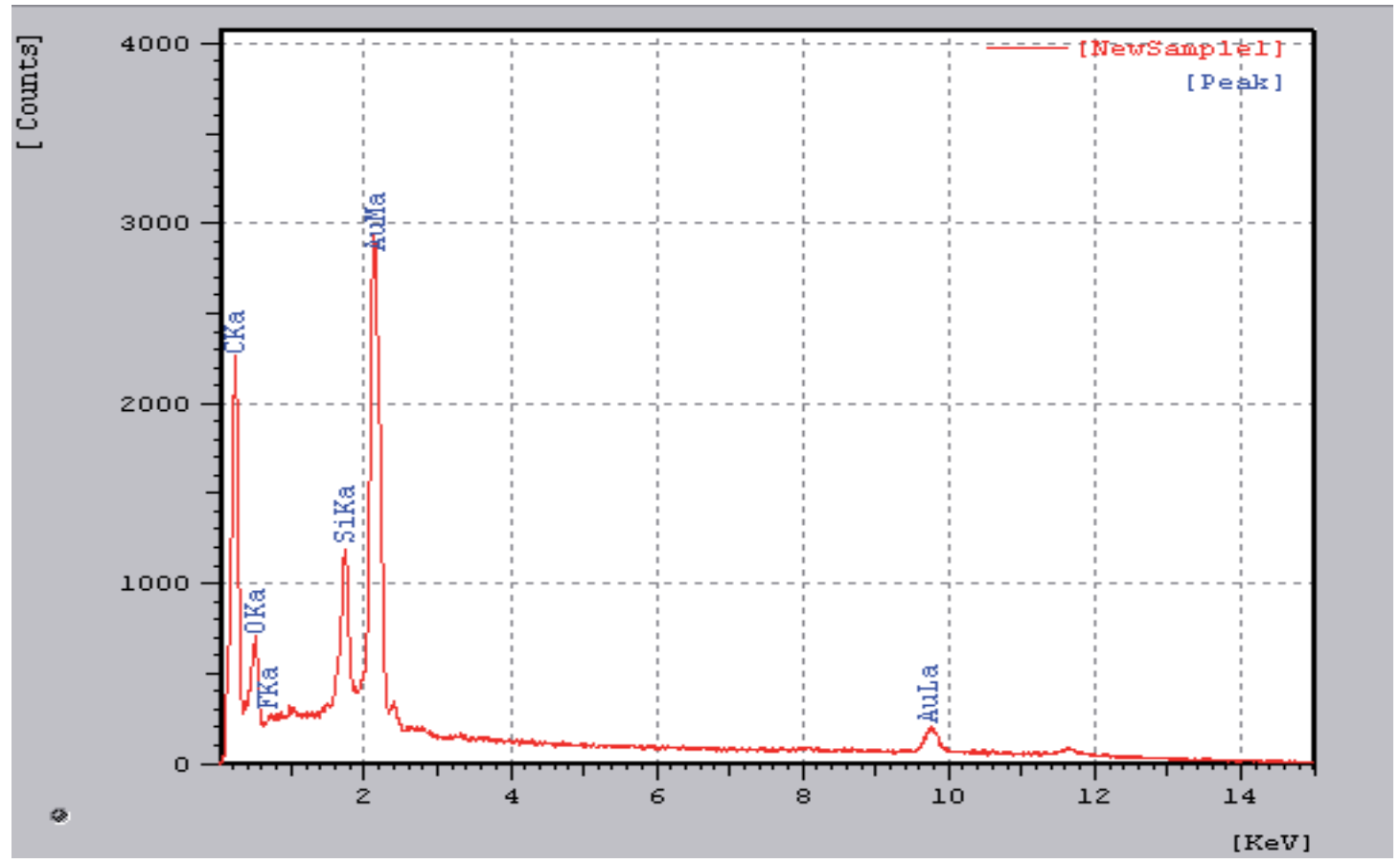

Figura 2 - Espectroscopia de energia dispersiva (EDS) realizada de amostra de papel grau cirúrgico submetida a três ciclos de esterilização com água destilada, demonstrando a presença dos elementos químicos $\mathrm{O}, \mathrm{Fe}, \mathrm{Na}, \mathrm{Si}, \mathrm{Au}, \mathrm{Cl}$ e $\mathrm{K}$

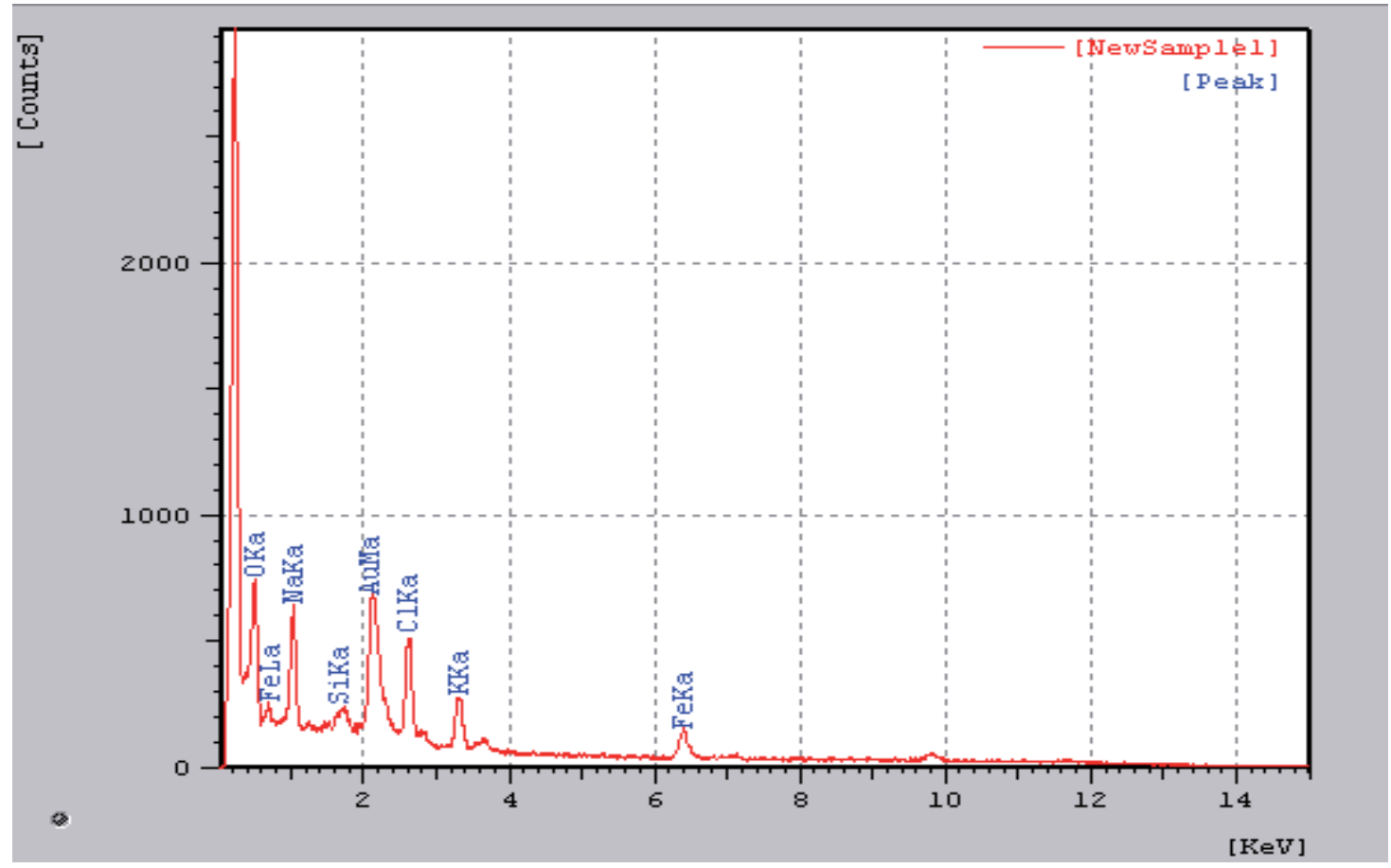


Tabela 2 - Percentagem em massa atômica (\%) dos elementos presentes no filme laminado (plástico) por análise EDS

\begin{tabular}{|c|c|c|c|c|c|c|c|}
\hline Elementos & Sem esterilizar & A.D. $1^{A}$ & A.D. $2^{B}$ & A.D. $3^{C}$ & A.F. $1^{D}$ & A.F. $2^{E}$ & A.F.3 ${ }^{\mathrm{F}}$ \\
\hline C & 74.09 & 22.87 & - & - & - & 30.47 & 40.55 \\
\hline $\mathbf{O}$ & 12.60 & 27.24 & & & & 25.33 & 19.34 \\
\hline Au & 13.29 & 2.68 & & & & & 39.52 \\
\hline $\mathbf{N}$ & & 47.20 & & & & 43.62 & \\
\hline $\mathrm{Na}$ & & & & & & 0.56 & \\
\hline Si & & & & & & & 0.58 \\
\hline Total & 99.98 & 99.99 & & & & 99.98 & 99.99 \\
\hline
\end{tabular}

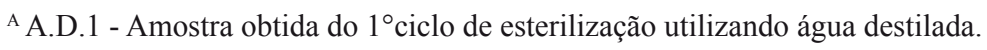

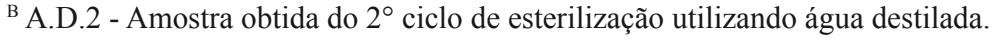

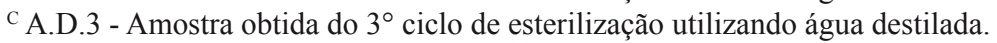

${ }^{D}$ A.F.1 - Amostra obtida do $1^{\circ}$ ciclo de esterilização utilizando água fluoretada.

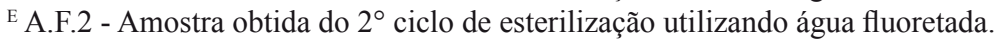

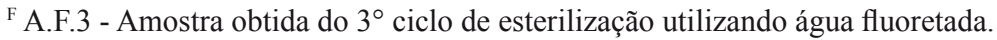

Os poros do papel permitem a passagem do vapor esterilizante. Dessa maneira, foi contabilizado o número desses poros em uma área $=191.288,74 \mu \mathrm{m}^{2}$, nas imagens obtidas com aproximação de 200 vezes em todas as amostras - os resultados estão apresentados na Tabela 3. Na Figura 3, a microscopia eletrônica de varredura $(200 \mathrm{X})$ revela a maior quantidade de poros e a menor largura entre as fibras, enquanto que em aumento de $2.400 \mathrm{X}$ pode-se observar a profundidade $\mathrm{e}$ a extensão de um poro (Figura 4). Na Figura 5, fica evidente a diminuição da quantidade dos poros $(\mathrm{p}<0,001$, Tabela 3) e o aumento da largura das fibras do papel grau cirúrgico na primeira utilização das embalagens. Ao submeter esses materiais consecutivamente em outros ciclos de esterilização com água destilada e ao simular a reutilização dos produtos, demonstra-se, na Figura 6, a significante diminuição dos poros ( $\mathrm{p}<0,001$, Tabela 3), acompanhada do sucessivo aumento das larguras das fibras tendendo ao total fechamento dos espaços (Figura 7), fato também observado nas Figuras 8,9 e 10 das amostras submetidas ao processo de esterilização sucessivo com água fluoretada $(\mathrm{p}<0,001$, Tabela 3).

Tabela 3 - Análise estatística do número de poros (média \pm desvio padrão, $n$ ) contabilizados em uma área de 191.288,74 $\mu \mathrm{m}^{2}$ das amostras

\begin{tabular}{|l|c|c|}
\hline Grupos & Média $\pm \mathbf{D P}(\mathbf{n})$ & $\boldsymbol{p}^{*}$ \\
\hline Sem esterilizar - Controle & $31,75 \pm 5,12(4)$ & $<0,001$ \\
\hline Água destilada 1 ciclo de esterilização & $12 \pm 1,83(4)$ & $<0,001$ \\
\hline Água destilada 2 ciclos de esterilização & $10 \pm 0,82(4)$ & $<0,001$ \\
\hline Água destilada 3 ciclos de esterilização & $7,25 \pm 2,50(4)$ & $<0,001$ \\
\hline Água fluoretada 1 ciclo de esterilização & $14,5 \pm 4,80(4)$ & $<0,001$ \\
\hline Água fluoretada 2 ciclos de esterilização & $13,5 \pm 2,08(4)$ & $<0,001$ \\
\hline Água fluoretada 3 ciclos de esterilização & $3,75 \pm 2,75(4)$ & \\
\hline
\end{tabular}

*versus controle - sem esterilizar 
Figura 3 - Papel grau cirúrgico não submetido a processo de esterilização (200X)

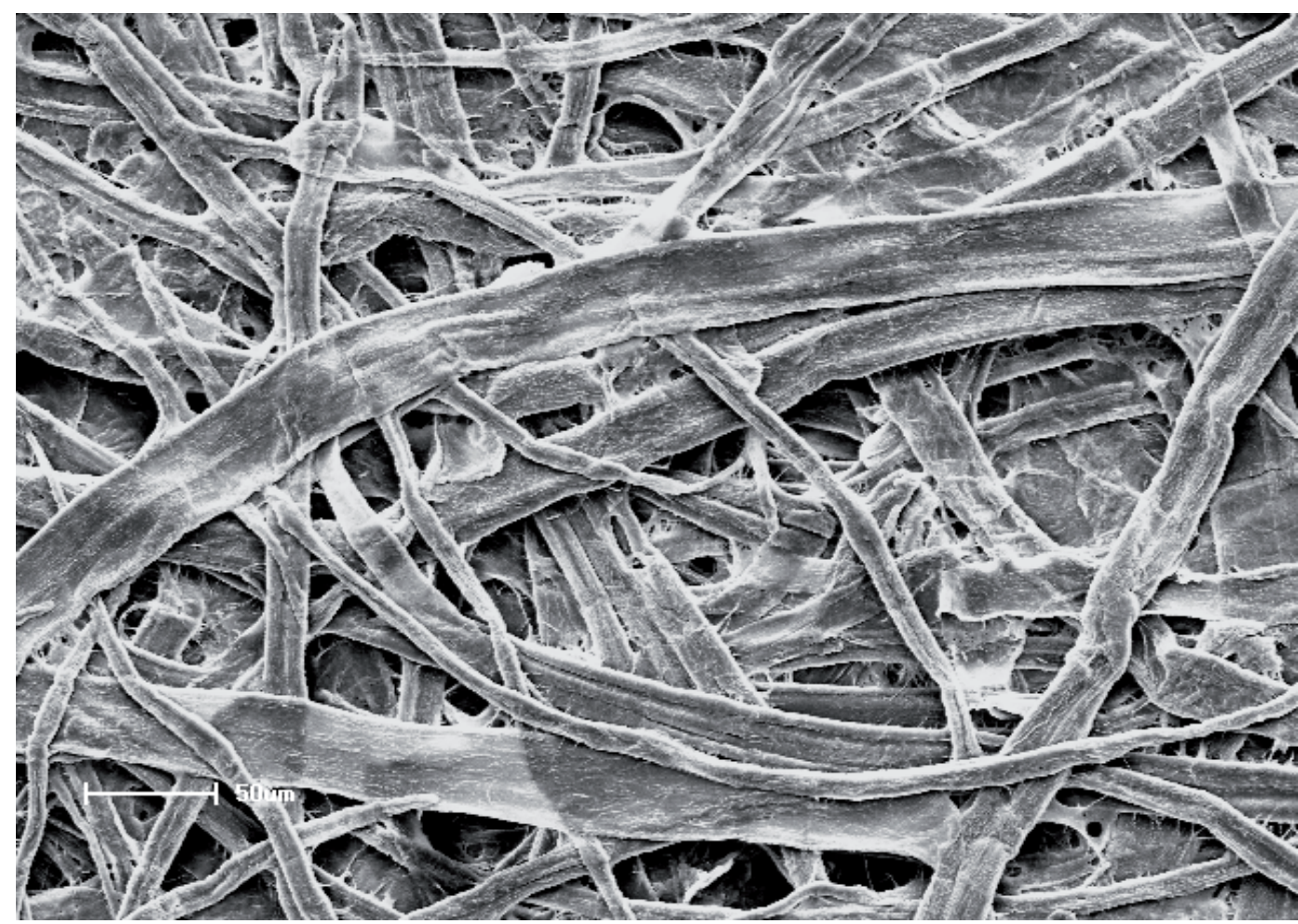

Figura 4 - Papel grau cirúrgico não submetido a processo de esterilização (2400X) mostrando a extensão do poro

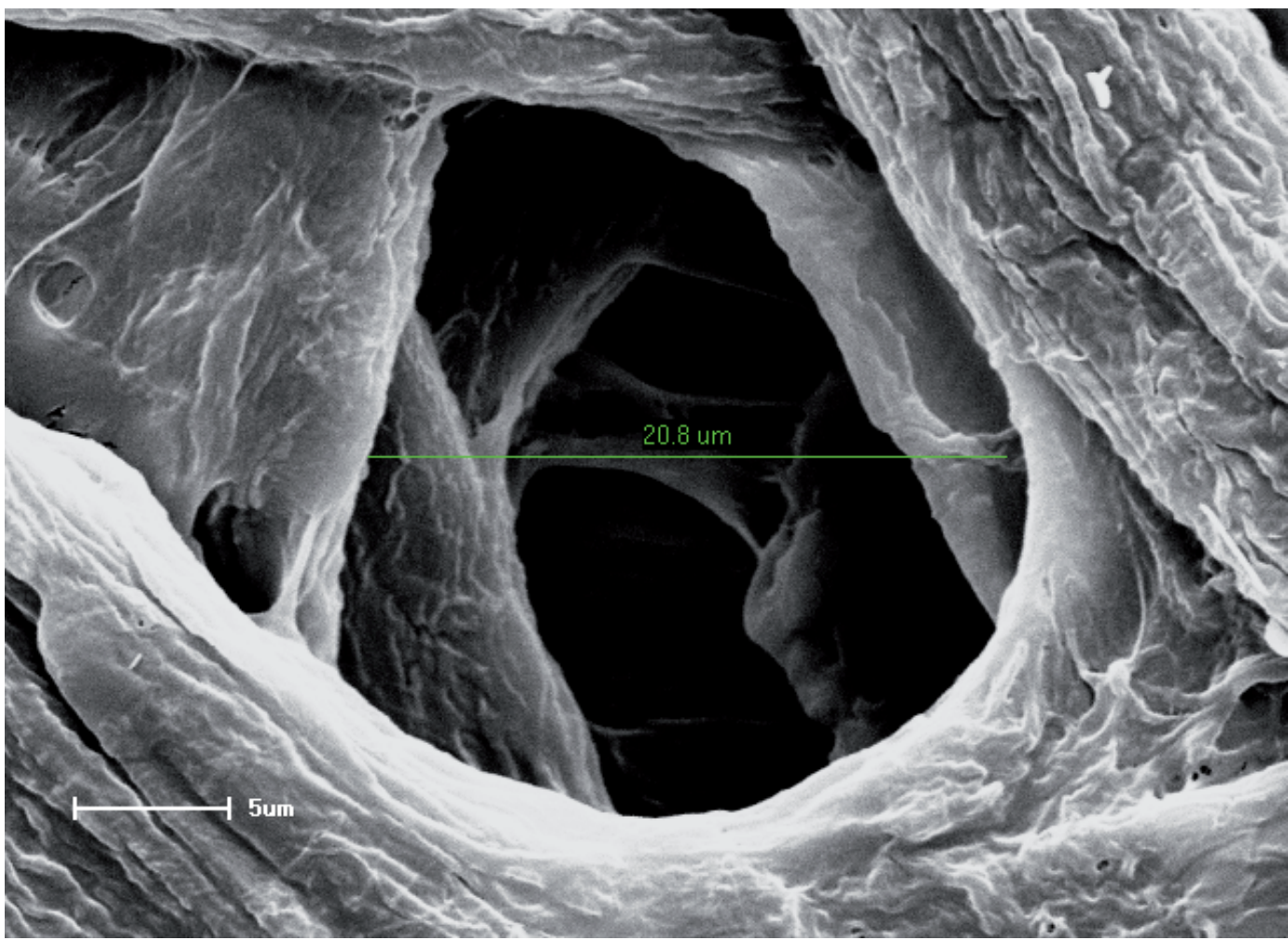


Figura 5 - Papel grau cirúrgico submetido a um ciclo de esterilização utilizando água destilada (200 X)

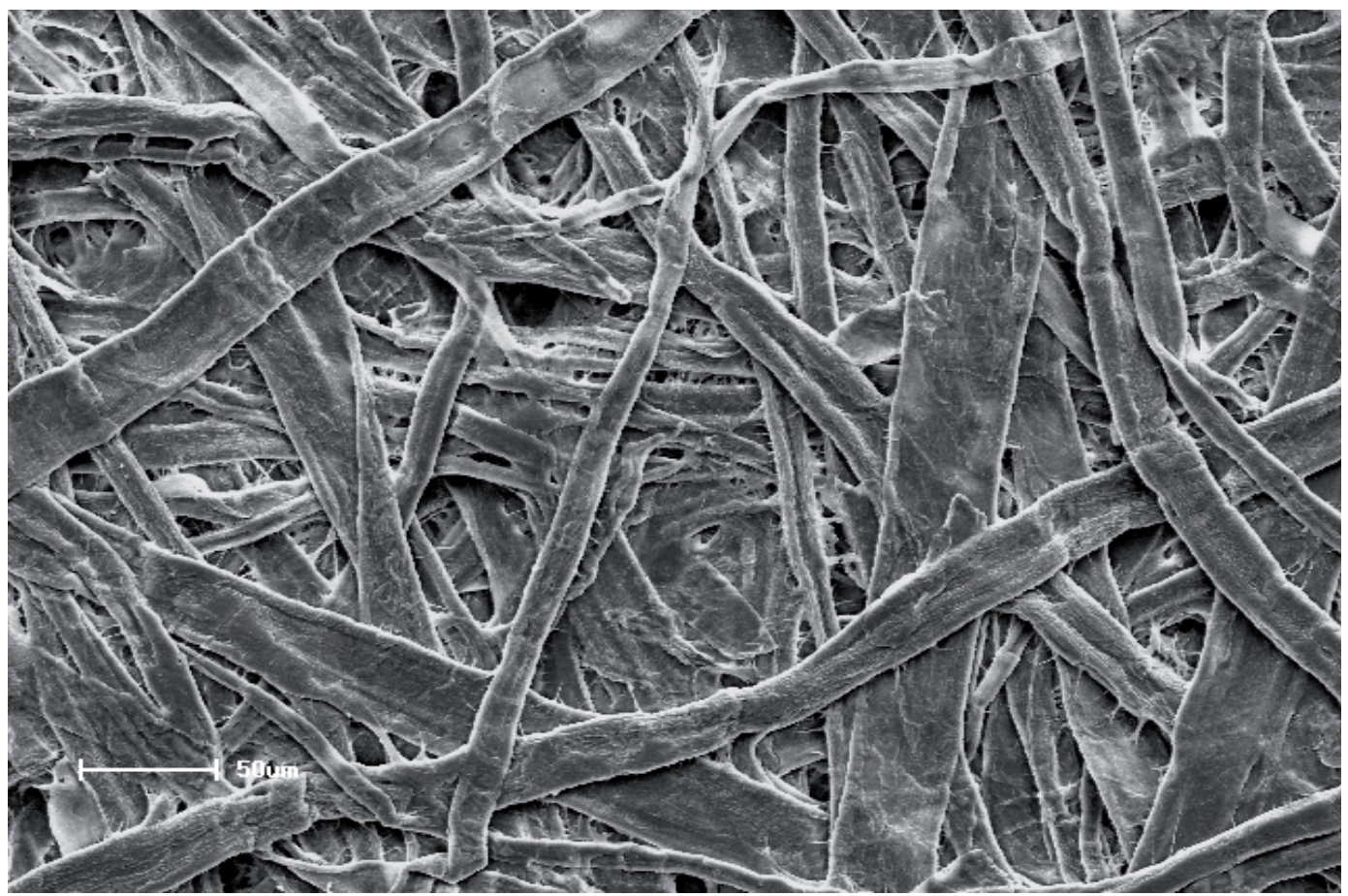

Figura 6 - Papel grau cirúrgico submetido a dois ciclos de esterilização utilizando água destilada (200 X)

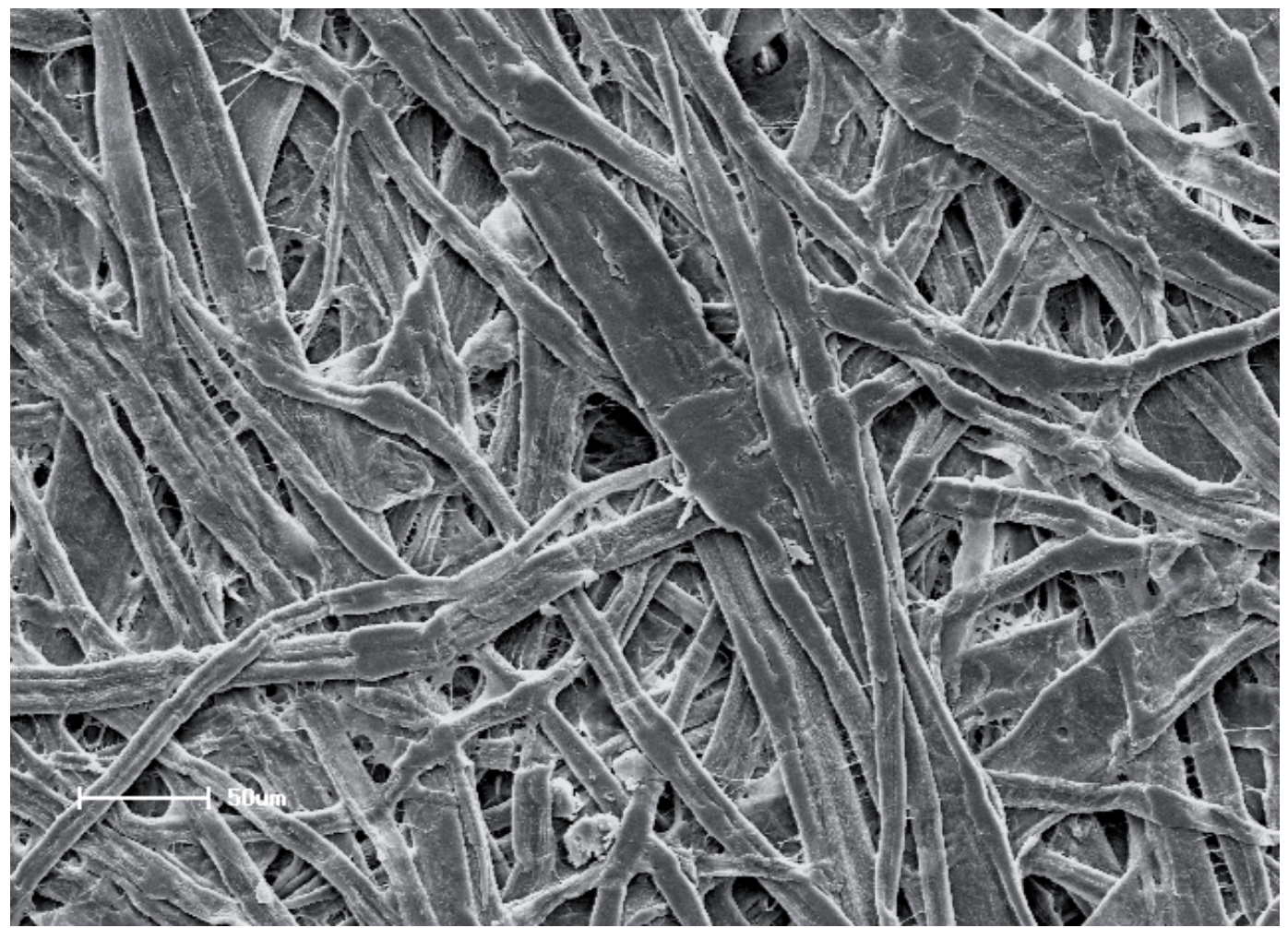


Figura 7 - Papel grau cirúrgico submetido a três ciclos de esterilização utilizando água destilada (200 X)

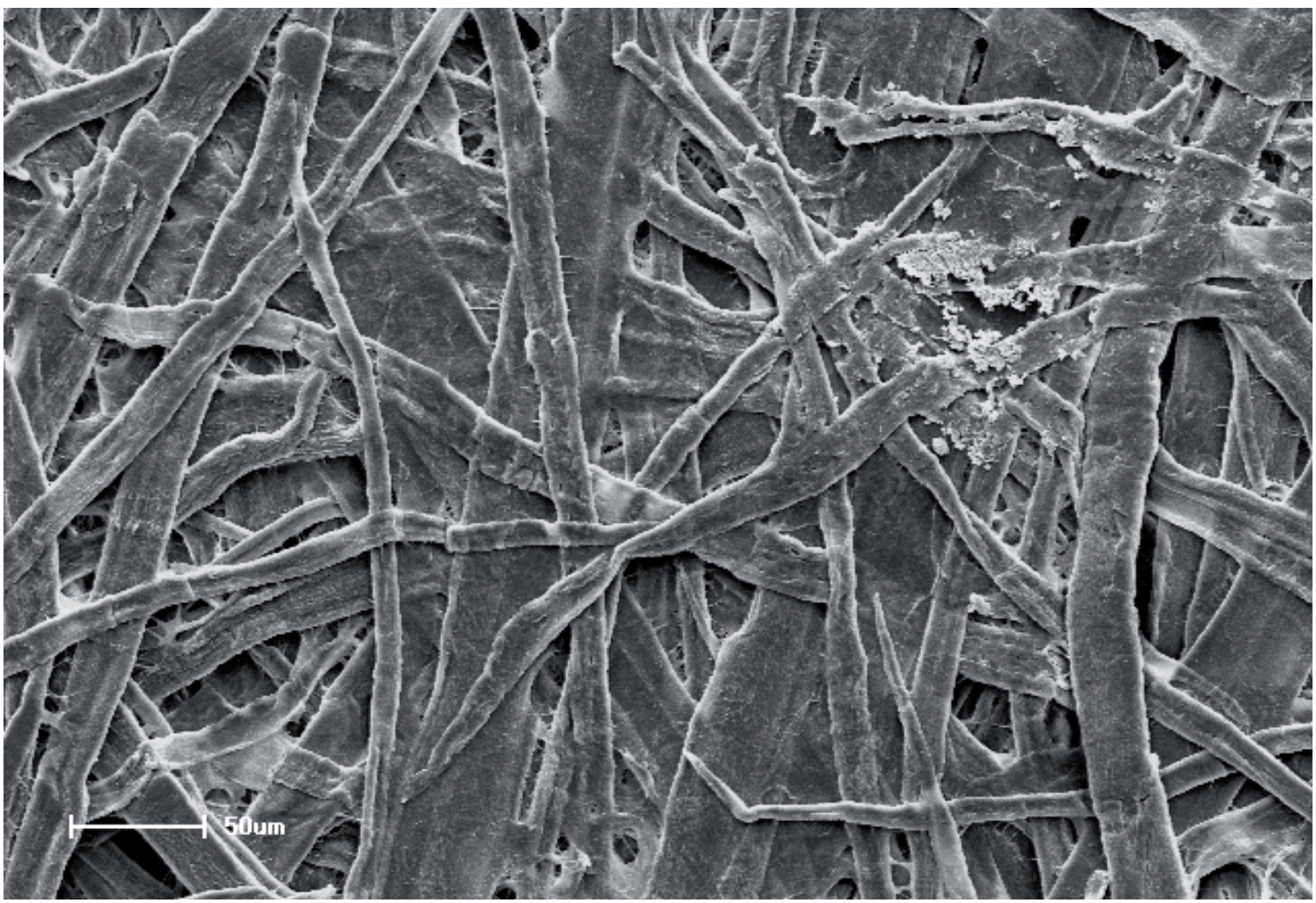

Figura 8 - Papel grau cirúrgico submetido a um ciclo de esterilização utilizando água fluoretada (200X)

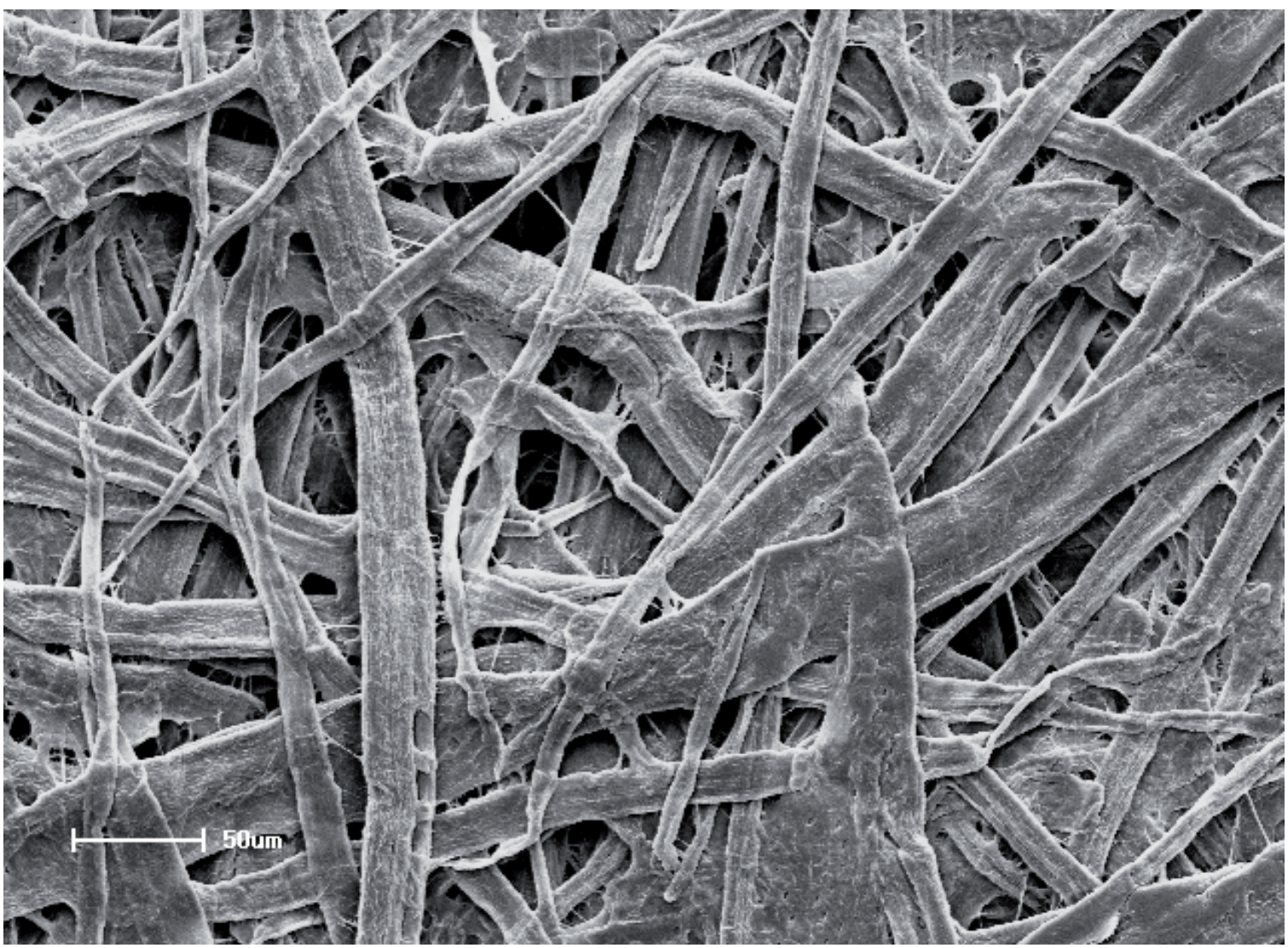


Figura 9 - Papel grau cirúrgico submetido a dois ciclos de esterilização utilizando água fluoretada (200X)

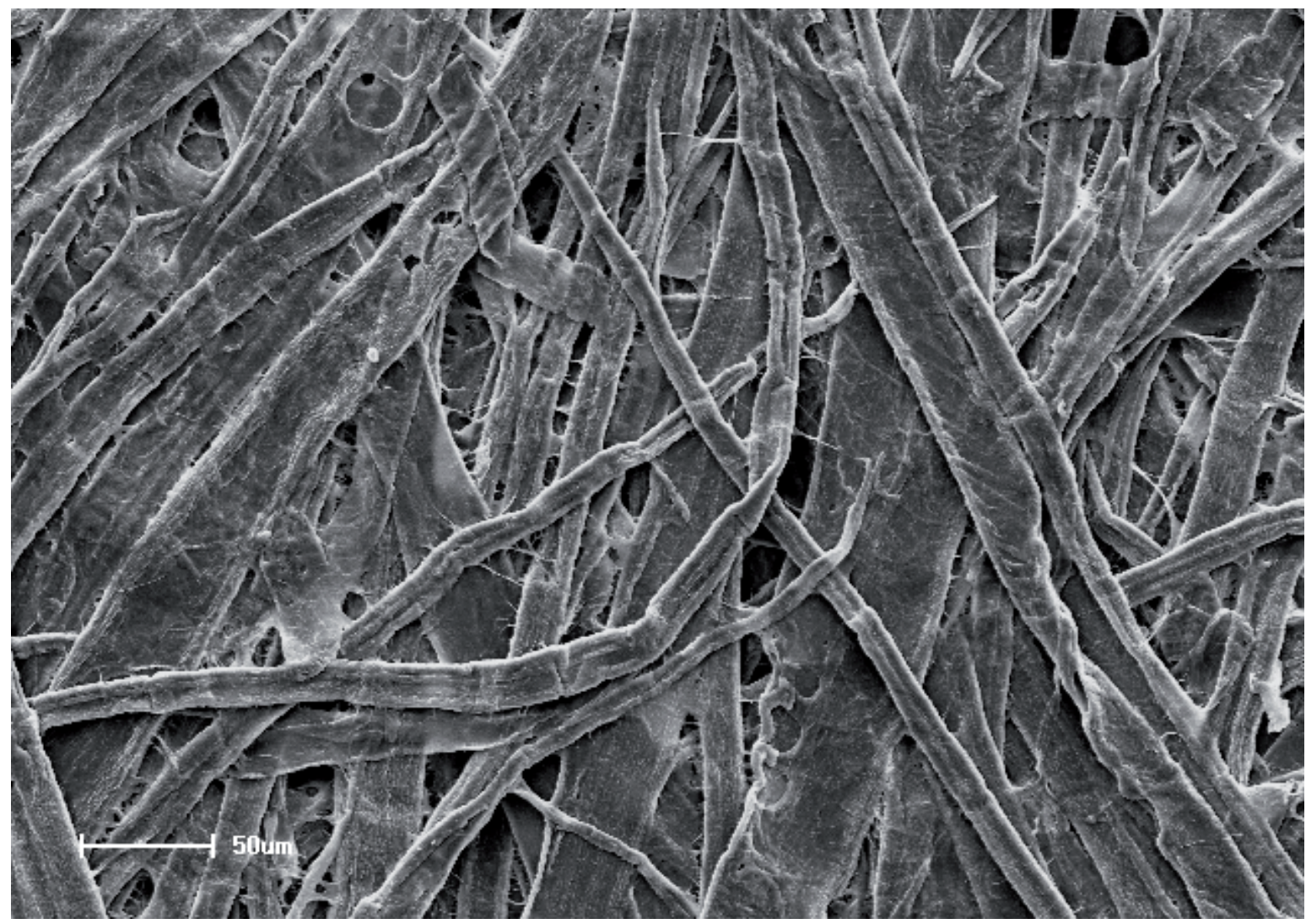

Figura 10 - Papel grau cirúrgico submetido a três ciclos de esterilização utilizando água fluoretada (200X)

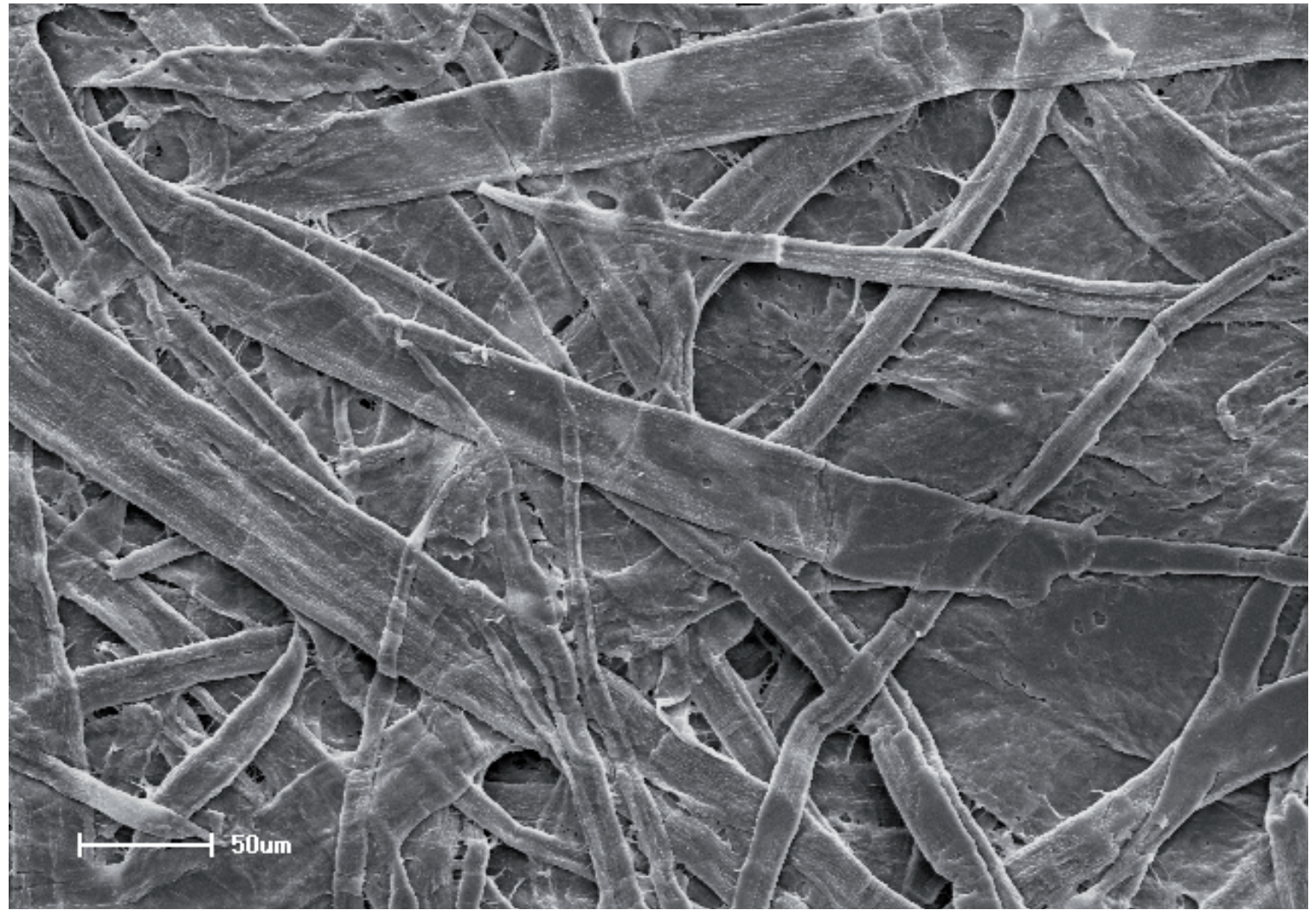


Na Tabela 4, estão representados os dados obtidos das larguras das fibras $(\mu \mathrm{m})$ contadas na área de 191.288,74 $\mu \mathrm{m}^{2}$ obtidas em aumento de $200 \mathrm{X}$ por meio de MEV, indicando um aumento das medidas $(\mathrm{p}<0,05)$, especialmente quando foram utilizadas água fluoretada e mais de um ciclo de esterilização (Figuras 9 e 10).

Tabela 4 - Largura das fibras $(\mu \mathrm{m})$ contadas na área de 191.288,74 $\mu \mathrm{m}^{2}$ obtidas em aumento de $200 \mathrm{X}$ por meio de $\mathrm{MEV}$

\begin{tabular}{|c|c|c|}
\hline Grupos & Média \pm DP (n) & $p$ \\
\hline Controle (sem esterilizar) & $25.07 \pm 11.03(69)$ & \\
\hline AD1 & $29,20 \pm 13,83(77)$ & ns $^{3}$ \\
\hline AD2 & $23,01 \pm 10,91(69)$ & ns \\
\hline AD3 & $\mathbf{2 6 , 0 4} \pm 12,30(68)$ & ns \\
\hline AF1 & $\mathbf{2 8 , 8 3} \pm 16.25(71)$ & ns \\
\hline AF2 $^{1}$ & $\mathbf{3 0 , 5 3} \pm 19,97(74)$ & $<\mathbf{0 , 0 5}$ \\
\hline AF3 $^{2}$ & $\mathbf{3 5 , 8 3} \pm \mathbf{2 6 , 8 9}(72)$ & $<\mathbf{0 , 0 5}$ \\
\hline & &
\end{tabular}

${ }^{1}$ versus AD2

${ }^{2}$ versus controle (sem esterilizar)

${ }^{3}$ não-significante versus controle
Os indicadores termoquímicos que foram impressos no papel grau cirúrgico reagiram quimicamente, indicando que foram submetidos à esterilização. Contudo, isso não foi possível notar em todos os ciclos, apenas no primeiro, pois, após mudança de cor do reagente, não há possibilidade de verificar outras alterações que indiquem nova esterilização depois do segundo e terceiro ciclos. Todos os testes químicos externos feitos com fita adesiva mudaram de cor, indicando que os materiais passaram pelos ciclos de esterilização. Os resultados com os integradores químicos internos classe 5, apresentados na Tabela 5, indicaram falhas no processo de esterilização quando as amostras foram submetidas a ciclos repetidos de esterilização com água destilada (Figuras 11, 12, 13, 14) - independentemente se as cubas com os materiais estavam voltadas para o papel ou para o filme laminado (plástico) da embalagem autoclavável (Figuras 11 e 12).

Tabela 5 - Resultados dos testes de eficácia de esterilização utilizando integrador químico interno da marca 3M Comply SteriGage ${ }^{\circledR}$ classe 5

\begin{tabular}{|c|c|c|c|c|c|c|}
\hline Ciclos & $\begin{array}{l}\text { A.D.1 }{ }^{\mathrm{A}} \\
\text { Papel* }^{*}\end{array}$ & $\begin{array}{c}\text { A.D.1 }^{\mathbf{A}} \\
\text { Plástico*** }^{*}\end{array}$ & $\begin{array}{l}\text { A.D. }{ }^{\text {B }} \\
\text { Papel* }\end{array}$ & $\begin{array}{c}\text { A.D.2 }{ }^{\text {B }} \\
\text { Plástico** }^{*}\end{array}$ & $\begin{array}{l}\text { A.D.3 } \\
\text { Papel* }\end{array}$ & $\begin{array}{c}\text { A.D.3 } \\
\text { Plástico** }\end{array}$ \\
\hline Aceito & X & X & & & X & \\
\hline Rejeitado & & & $\mathrm{X}$ & $\mathrm{X}$ & & $\mathrm{X}$ \\
\hline Ciclos & $\begin{array}{l}\text { A.F.1 } \\
\text { Papel* }\end{array}$ & $\begin{array}{c}\text { A.F.1 }^{\text {D }} \\
\text { Plástico*** }^{*}\end{array}$ & $\begin{array}{l}\text { A.F.2 } \\
\text { Papel* }\end{array}$ & $\begin{array}{c}\text { A.F.2 }{ }^{\mathrm{E}} \\
\text { Plástico*** }^{2}\end{array}$ & $\begin{array}{l}\text { A.F.3 } \\
\text { Papel* }\end{array}$ & $\begin{array}{c}\text { A.F.3 } \\
\text { Plástico** }\end{array}$ \\
\hline Aceito & $X$ & $X$ & $\mathrm{X}$ & $\mathrm{X}$ & $X$ & $X$ \\
\hline Rejeitado & & & & & & \\
\hline
\end{tabular}

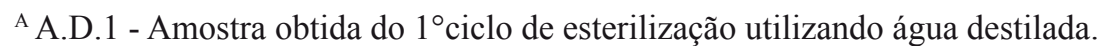

${ }^{\text {B }}$ A.D. 2 - Amostra obtida do $2^{\circ}$ ciclo de esterilização utilizando água destilada.

${ }^{C}$ A.D. 3 - Amostra obtida do $3^{\circ}$ ciclo de esterilização utilizando água destilada.

${ }^{D}$ A.F.1 - Amostra obtida do $1^{\circ}$ ciclo de esterilização utilizando água fluoretada.

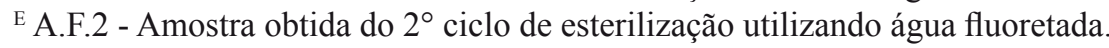

${ }^{\text {F }}$ A.F.3 - Amostra obtida do $3^{\circ}$ ciclo de esterilização utilizando água fluoretada.

* Papel - Os recipientes com as amostras estavam com suas aberturas viradas para o papel da embalagem.

** Plástico - Os recipientes com as amostras estavam com suas aberturas viradas para o plástico/filme laminado da embalagem. 
Figura 11 - Resultado de teste de indicador químico rejeitado, colocado em recipiente virado para o plástico da embalagem, após segundo ciclo de esterilização com água destilada

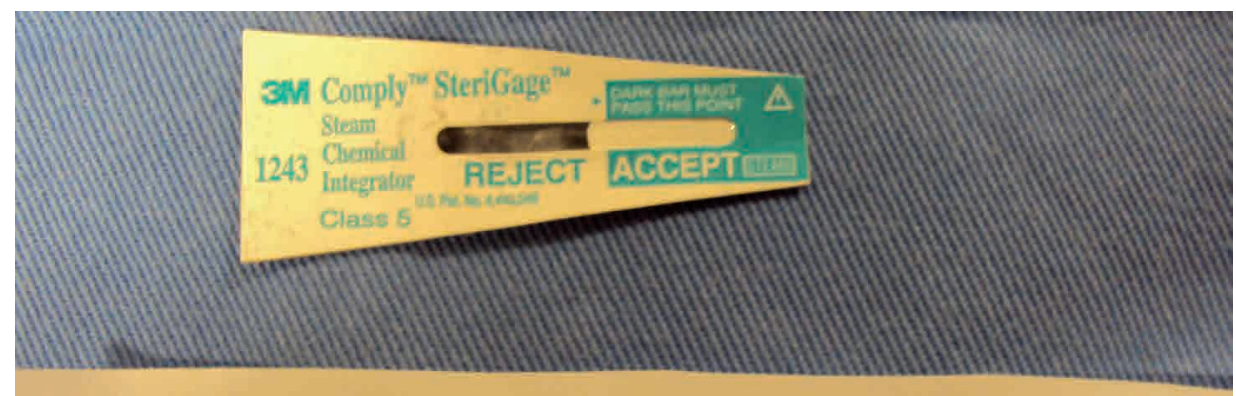

\section{CICLO 2 - AGUA DESTILADA - QUIMICO - PLÁSTICO}

Figura 12 - Resultado de teste de indicador químico rejeitado, colocado em recipiente virado para o papel da embalagem, após segundo ciclo de esterilização com água destilada

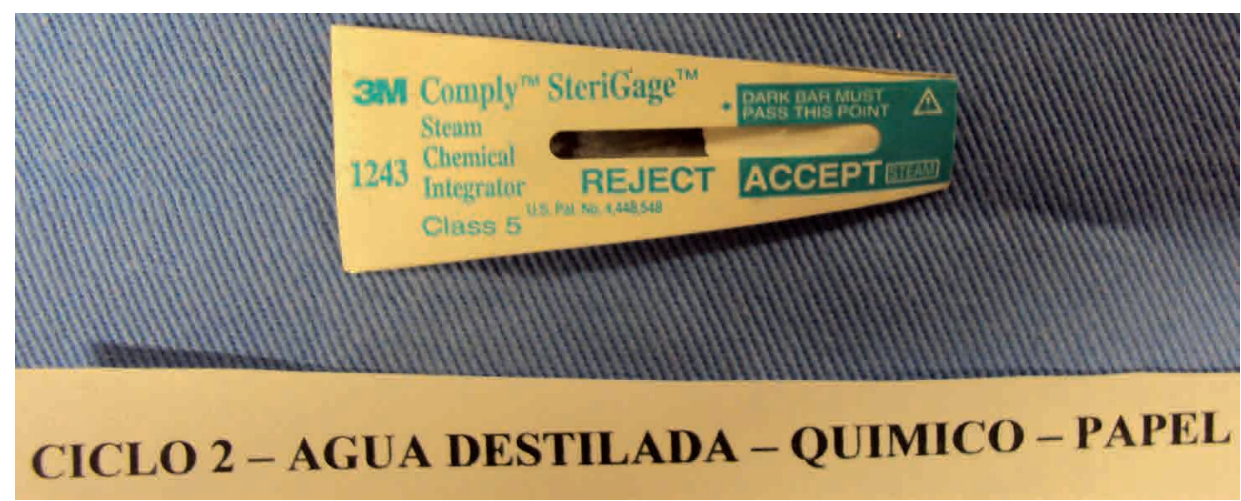

Figura 13 - Resultado de teste de indicador químico rejeitado, colocado em recipiente virado para o plástico da embalagem, após terceiro ciclo de esterilização com água destilada

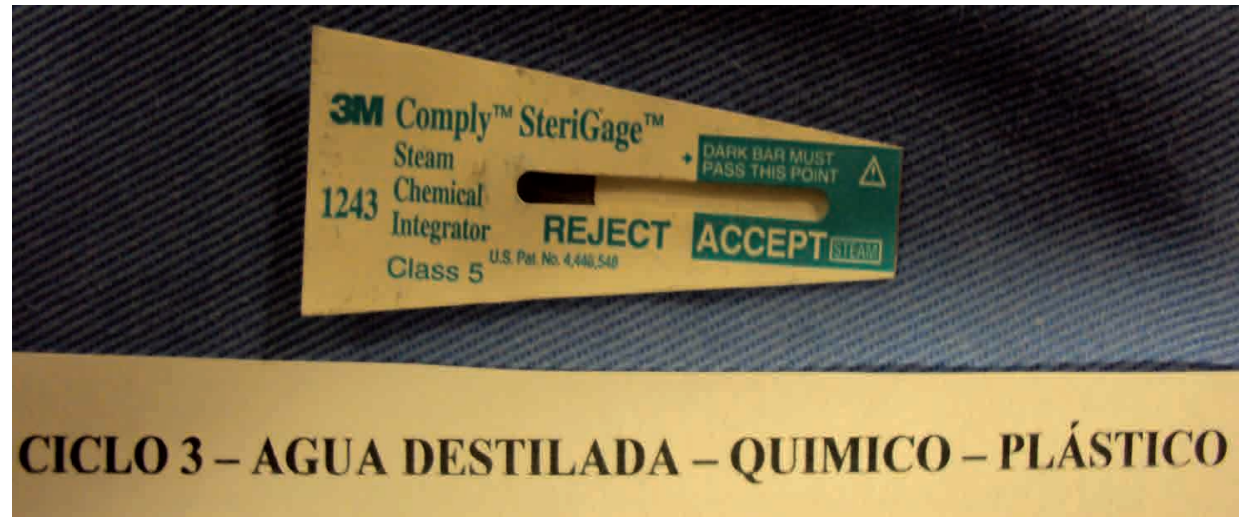

Figura 14 - Resultado de teste de indicador químico aceito, colocado em recipiente virado para o papel da embalagem, após terceiro ciclo de esterilização com água destilada

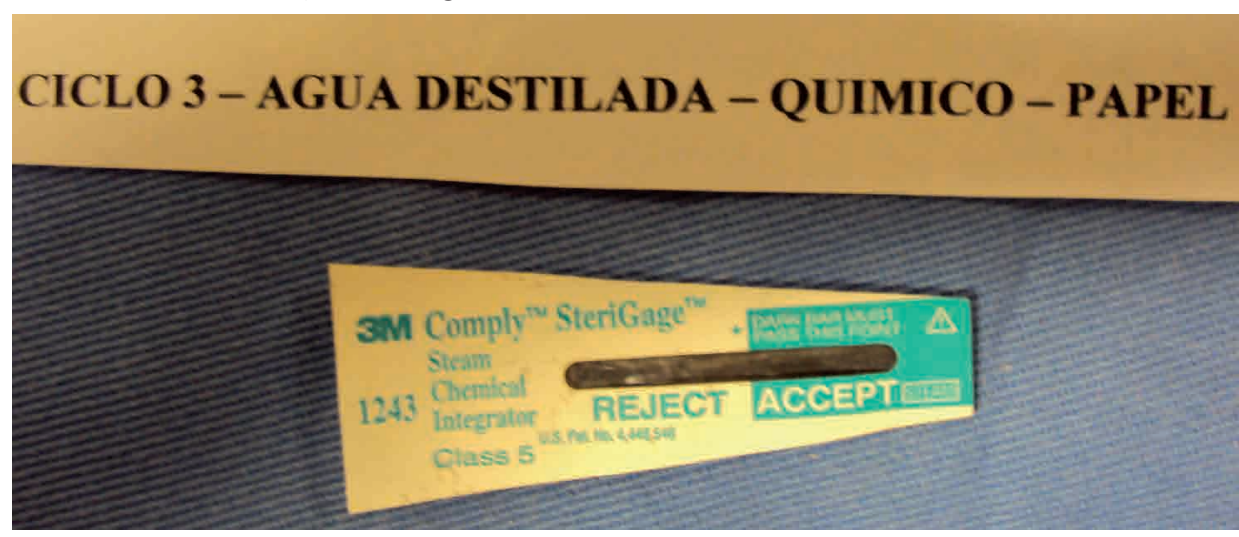


Após incubação das ampolas de testes biológi$\cos$, foi identificado que não houve proliferação de bactérias em nenhum indicador que passou pelas repetidas e diferentes condições de esterilização. Se o indicador não fosse adequadamente esterilizado, resultaria em mudança de cor indicando proliferação microbiana, o que não foi observado nas amostras testadas. A Tabela 6 apresenta os resultados obtidos nos testes de esterilização biológicos realizados com o Attest $1262^{\circledR}$ B.I./ Steam/3M.

Tabela 6 - Resultados dos testes de esterilização biológico interno da marca $3 \mathrm{M}$ - Attest $1262^{\circledR}$ B.I./Steam

\begin{tabular}{|c|c|c|c|c|c|c|}
\hline Ciclos & $\begin{array}{l}\text { A.D. }{ }^{\mathrm{A}} \\
\text { Papel }^{*}\end{array}$ & $\begin{array}{c}\text { A.D.1 }^{\text {A }} \\
\text { Plástico }^{* *}\end{array}$ & $\begin{array}{l}\text { A.D. } 2^{\text {B }} \\
\text { Papel }^{*}\end{array}$ & $\begin{array}{l}\text { A.D.2 }^{\text {B }} \\
\text { Plástico }^{* *}\end{array}$ & $\begin{array}{l}\text { A.D.3 } \\
\text { Papel }^{*}\end{array}$ & $\begin{array}{c}\text { A.D.3 }^{\text {C }} \\
\text { Plástico }^{* *}\end{array}$ \\
\hline Aceito & $X$ & $X$ & $X$ & $X$ & $X$ & $X$ \\
\hline \multicolumn{7}{|l|}{ Rejeitado } \\
\hline Ciclos & $\begin{array}{l}\text { A.F.1 } \\
\text { Papel }^{\text {" }}\end{array}$ & $\begin{array}{c}\text { A.F.1 } \\
\text { Plástico }^{\text {D** }}\end{array}$ & $\begin{array}{l}\text { A.F.2 } \\
\text { Papel }^{\text {E }}\end{array}$ & $\begin{array}{c}\text { A.F.2 }^{\mathrm{E}} \\
\text { Plástico }^{* * *}\end{array}$ & $\begin{array}{l}\text { A.F.3 } \\
\text { Papel }^{*}\end{array}$ & $\begin{array}{c}\text { A.F.3 } \\
\text { Plástico }^{* * *}\end{array}$ \\
\hline Aceito & $\mathrm{X}$ & $\mathrm{X}$ & $\mathrm{X}$ & $\mathrm{X}$ & $\mathrm{X}$ & $X$ \\
\hline Rejeitado & & & & & & \\
\hline
\end{tabular}

${ }^{\mathrm{A}}$ A.D. 1 - Amostra obtida do $1^{\circ}$ ciclo de esterilização utilizando água destilada.

${ }^{B}$ A.D. 2 - Amostra obtida do $2^{\circ}$ ciclo de esterilização utilizando água destilada.

${ }^{c}$ A.D. 3 - Amostra obtida do $3^{\circ}$ ciclo de esterilização utilizando água destilada.

D A.F.1 - Amostra obtida do $1^{\circ}$ ciclo de esterilização utilizando água fluoretada.

${ }^{\text {E }}$ A.F. 2 - Amostra obtida do $2^{\circ}$ ciclo de esterilização utilizando água fluoretada.

F A.F.3 - Amostra obtida do $3^{\circ}$ ciclo de esterilização utilizando água fluoretada.

* Papel - Os recipientes com as amostras estavam com suas aberturas viradas para o papel da embalagem.

** Plástico - Os recipientes com as amostras estavam com suas aberturas viradas para o plástico/filme laminado da embalagem.

\section{DISCUSSÃO}

O processo de esterilização de materiais termo resistentes utilizados na assistência à saúde que oferece maior segurança é o vapor saturado sob pressão, realizado em autoclaves. O mecanismo de ação desse método é a termocoagulação e a desnaturação de enzimas e proteínas estruturais da célula microbiana (PINTER; GABRIELLONI, 2000; RUTALA; WEBER, 2008). A esterilização em autoclave úmida consiste no vapor de água, cujo monitoramento mecânico verifica o tempo, temperatura e pressão (AORN, 2005) que são registrados pelo operador, por uma impressora ou por um dispositivo eletrônico (SOBECC, 2009). Apesar de a água fluoretada, que faz o abastecimento urbano, ser potável, não possui pureza suficiente para essa aplicação. Essa água possui óxidos, sais dissolvidos, metais pesados provenientes dos tubos de distribuição corroídos, que provocam corrosão do instrumental. Além disso, o cloreto de sódio junto ao desequilíbrio do $\mathrm{pH}$ causa incrustação de precipitados minerais não passíveis de remoção com a lavagem do instrumental. Há métodos para remoção de impurezas, mas nenhum remove todos os contaminantes até níveis baixos para se ter uma água de qualidade. Dessa maneira, recomenda-se utilizar água desmineralizada, destilada ou osmose reversa (COUTO et al., 2009; ABNT, 2005a; ABNT, 2005b; SOBECC, 2009). Os resultados da espectroscopia de energia dispersiva indicaram que as amostras submetidas à esterilização com uso de água fluoretada apresentaram elementos que não aparecem com o uso de água destilada em embalagens autoclaváveis com uso único, como silício, flúor, cálcio, zinco e carbono, comprovando a possibilidade de corrosão dos instrumentais embalados. As embalagens sendo reutilizadas com o uso de água destilada demonstraram o aparecimento de outros compostos, como nitrogênio, sódio, magnésio, cloro, potássio, ferro e carbono em importante quantidade, indicando que a incrustação de precipitados pode realmente acontecer, embora não tenham sido encontrados na literatura dados semelhantes para se comparar.

Os indicadores químicos são classificados pela norma ANSI/AAMI/ISSO 11140-1 (2005) e são registrados por indicadores e integradores químicos, encontrados na forma de tiras de papel que contém tinta termocrômica que muda de cor após passar pelo processo de esterilização (SOBECC, 2009). Os indicadores químicos externos evidenciam apenas que o artigo foi submetido ao processo de esterilização, distinguindo dos pacotes não processados; não garantindo, portanto, a eficácia dentro da câmara de esterilização. Para uso em autoclave a vapor, são encontrados na forma de fitas adesivas com listras em diagonal e combinações de papel e plástico, contendo sais de prata que sofrem oxidação (COUTO et al., 2009). Os 
indicadores químicos internos verificam um ou mais parâmetros de esterilização e são divididos nas classes III, IV, V, VI. São armazenados dentro dos pacotes e encontrados na forma de tubos, tiras de papel e integradores. Esses integradores possuem um mostrador que reage progressivamente de acordo com a temperatura, tempo de exposição e a presença do vapor. Alguns indicadores químicos internos durante os testes foram rejeitados, demonstrando que ciclos sucessivos não permitem um processo de esterilização adequado. Isso decorre devido à reutilização das embalagens em ciclos sucessivos que diminui o número de poros. Além disso, foram constatados o aumento da largura das fibras, a diminuição dos espaços e a extensão dos poros. Esses fatores dificultam a passagem do vapor úmido para a esterilização, impedindo, dessa forma, que todos os instrumentais embalados possam em todas as suas faces e regiões serem atingidos pelo vapor esterilizante, aumentando o risco de falhas e diminuindo a eficácia e a eficiência do processo.

Embora alguns integradores químicos da classe V utilizados neste estudo indicaram inconsistência do processo de esterilização, antagonicamente a esses resultados, os indicadores biológicos demonstraram que as condições foram suficientemente adequadas para alcançar a esterilização. Os indicadores biológicos servem para comprovar a morte microbiana após o processo de esterilização, classificados em três categorias. Esse controle é caracterizado pela presença de esporos bacterianos Geobacillus Stearothermophilus (COUTO et al., 2009; SOBECC, 2009).

O princípio da esterilização a vapor exige que os pacotes sejam cuidadosamente preparados para favorecer o contato com o agente esterilizante com todos os itens dentro dos pacotes. Segundo a ANSI/ AAMI ST46(2002) e Schneider et al.(2005), algumas práticas podem impedir a remoção de ar e a penetração ao redor e ao longo de toda a carga resultando em um indicador químico rejeitado. Isso poderia justificar por que algumas amostras foram rejeitadas em testes químicos e aprovadas em testes biológicos. Algumas dessas condições, como colocar os pacotes com muita proximidade; permitir que o lado do plástico dos invólucros fique no mesmo sentido; não deixar inclinado os pacotes impedindo que ocorra um fluxo de vapor adequado entre eles; não ter cuidado ao empilhar bandejas e recipientes mesmo perfurados; não permitir a presença de espaços entre os pacotes; não dispor as bandejas paralelamente às prateleiras, dentre outras, poderiam ser listadas como importantes variáveis durante o processo de esterilização.

A propriedade que determina a barreira dos micro-organismos é o diâmetro dos poros, cuja esterilização a vapor não deve ser superior a $50 \mu \mathrm{m}$; e a propriedade que determina a passagem do vapor esterilizante é chamada porosidade ou permeância do ar, que, para esterilização a vapor, deve ser no mínimo 3,4 $\mu \mathrm{m} /$ PA.s (ABNT, 2005b). Os resultados encontrados nas imagens do MEV demonstraram que ocorre a deformação do estado inicial das embalagens autoclaváveis, fazendo com que as características físicas dos produtos sejam alteradas e as características químicas variem na presença do vapor úmido esterilizante produzido por água destilada ou fluoretada.

Dessa maneira, o processo de empacotamento e esterilização dos artigos é de extrema importância para garantia da manutenção da esterilidade dos produtos odontológicos, médicos e hospitalares (OLIVEIRA et al., 2011a). Os sistemas de embalagem devem manter a segurança dos produtos, de modo que possam ser armazenados e transportados adequadamente, preservando a esterilidade e a integridade dos materiais (CARVALHO, 2015). Entretanto, a existência de variáveis que decorrem do uso diário desses processos (BRITO et al., 2002; OLIVEIRA et al., 2011b; GONÇALVES et al., 2015) necessita constantemente ser reavaliada e sustentada por testes de validação e pesquisa que tragam evidências de segurança. E, sobretudo, é preciso atualizações, face ao lançamento contínuo de novos produtos no mercado (COSTA et al., 2011) que poderiam diminuir os custos dos processamentos da esterilização.

\section{CONCLUSÕES}

De acordo com os resultados obtidos e as limitações do trabalho, concluiu-se que, em relação ao uso das embalagens para esterilização avaliadas neste trabalho, deve-se seguir as orientações do fabricante e das normas da ABNT NBR, que indicam a sua utilização por uso único. A reutilização das embalagens causa deformações físicas, colocando em risco a eficácia da esterilização do material embalado, e aumenta o risco de prejuízo do material esterilizado por contaminação com material inorgânico. Além disso, o processo de esterilização somente poderá ser validado se for confirmado por meio da utilização de testes químicos 
e biológicos internos. A utilização de água fluoretada no processo de esterilização em autoclave por vapor úmido pode prejudicar os materiais embalados pela precipitação de silício, flúor e carbono. Por fim, deve-se orientar acadêmicos e profissionais da área da saúde sobre como processar o material a ser esterilizado.

\section{REFERÊNCIAS}

AGÊNCIA NACIONAL DE VIGILÂNCIA SANITÁRIA. ANVISA RDC 307: Altera a Resolução n.50, de 21 de Fevereiro de 2002, que Dispõe sobre o regulamento técnico para planejamento, programação, elaboração e avaliação de projetos físicos em estabelecimentos assistenciais de saúde. Brasília, 14/ Nov/ 2002. Disponível em http://www.anvisa. gov.br/legis

AGÊNCIA NACIONAL DE VIGILÂNCIA SANITÁRIA. ANVISA RE 2605: Estabelece a lista de produtos médicos enquadrados como de uso único proibidos de ser reprocessados. Brasília, 11/ Ago/ 2006. Disponível em htttp: //www.anvisa.gov.br/legis

AMERICAN NATIONAL STANDARDS INSTITUTE. ASSOCIATION FOR ADVANCEMENT OF MEDICAL INSTRUMENTATION. ANSI/AAMI/ISO 1140-1: Sterilization of health care products - chemical indicators Parte 1: General requirements. Arlington, 2005.

AMERICAN NATIONAL STANDARDS INSTITUTE. ASSOCIATION FOR ADVANCEMENT OF MEDICAL INSTRUMENTATION. ANSI/AAMI ST46: Steam sterilization and sterility assurance in health care facilities. Arlington, 2002.

ASCARI, R.A. et al. O processo de esterilização de materiais em serviços de saúde: uma revisão integrativa. Brazilian Journal of Surgery and Clinical Research. v.4, n.2, p.:3338, 2013.

ASSOCIAÇÃO BRASILEIRA DE NORMAS TÉCNICAS. ABNT NBR 14990: Sistemas e materiais de embalagens para esterilização de produtos de saúde. Rio de Janeiro, 2005.

ASSOCIAÇÃO BRASILEIRA DE NORMAS TÉCNICAS. ABNT NBR 14990-2: Sistemas de embalagens para esterilização de produtos para a saúde. Parte2: papel grau cirúrgico para fabricação de embalagens para esterilização a vapor saturado sob pressão. Rio de Janeiro, 2005.

ASSOCIATION OF PERIOPERATIVE REGISTERED NURSES. AORN: Standards, recommended practices, guidelines. Denver; 2005.

BRITO, M.F.P. et al. Validação do processo de esterilização de artigos médico-hospitalares segundo diferentes embalagens. Rev. Bras. Enferm. v. 55, n. 4, p. 414-419, 2002.
CARVALHO, R. Enfermagem em centro de material, biossegurança e bioética. São Paulo, Ed Manole, 2015. $406 \mathrm{p}$.

COSTA, E.A.M. et al. Reprocessamento de produtos médicos: uma proposta de modelo regulatório para hospitais brasileiros. Rev. Esc. Enferm. USP. v.45, n. 6, p.1459-65, 2011.

COUTO R.C. et al. Infecção hospitalar e outras complicações não-infecciosas da doença: epidemiologia, controle e tratamento. $4^{\mathrm{a}}$ Ed. Rio de Janeiro, Guanabara Koogan, 2009. 832 p.

DINIZ,A.R. et al. Reutilização de embalagens autoclaváveis: uma prática condenável. In: XI Encontro de Pesquisa da UEPG, Ponta Grossa. Anais do XI Encontro de Pesquisa da Universidade Estadual de Ponta Grossa - Ponta Grossa/PR - 13 e 15 de Agosto de 2013.

GONÇALVES, R.C.S. et al. Operational practice of the nurse in the center of material and sterilization: an integrative review. J Nurs UFPE. v.9, n.2, p.: 745-749, 2015.

OLIVEIRA, C.A.S. et al. Avaliação microbiológica do processo de esterilização de artigos odontológicos segundo embalagens primárias e secundárias. Odontol. Clin.-Cient. v. 10, n. 4 , p. 361-365, 2011a.

OLIVEIRA, C.A.S. et al. Avaliação microbiana da recontaminação de artigos odontológicos estéreis segundo o manuseio das embalagens. RFO Passo Fundo. v. 16, n.3, p. 256-260, 2011b.

PINTER, M.G.; GABRIELLONI, M.C. Central de material e esterilização. In: FERNANDES, A.T. et al. Infecção hospitalar e suas interfaces na área da saúde. São Paulo, Atheneu, 2000. p. 1041-60.

RUTALA, W.A.; WEBER, D.J. Guideline for desinfection and sterilization in healthcare facilities. Centers for Disease Control. 2008. Disponivel em: http: //www.cdc.gov

SCHNEIDER, P.M. et al. Performance of various steam sterilization indicator under optimum and sub-optimum exposure conditions. Am J Infect Control. v.33, n.5 Suppl 2, p. 555-67, 2005.

SOCIEDADE BRASILEIRA DE ENFERMEIROS DE CENTRO CIRÚRGICO. SOBECC: Práticas recomendadas - centro cirúrgico, recuperação pós-anestésica e centro de material e esterilização. $5^{\text {a }}$ Ed. São Paulo, 2009. 